\title{
Interpreting public policy dilemmas: discourse analytical insights
}

Ian Wash (1D ${ }^{1 凶}$

This article explains the value of discourse analysis for interpreting the construction and resolution of policy dilemmas in the field of international education. Its case material is drawn from official documents relating to international education policy, published by global bodies such as the United Nations and World Bank from 2000 to 2018, explored with two purposes in mind. The first is empirical, the analysis revealing how a dominant 'liberal' model governing international education was discursively constructed as a grand narrative about the purpose and intended outcomes in international education. This is achieved by applying an interpretive discourse analytical approach, customised for this particular policy puzzle, to the international education corpus. The article's second purpose is methodological, to reflect on the various criticisms and supposed limitations of using discourse analysis as a tool of public policy analysis. This part of the article argues that the discourse approach can equip analysts with a reliable tool-kit for carrying out research into the subtle and often unrecognised ways in which ideas and beliefs inform global education policy practices. A systematic discourse analysis reveals the tensions and sometimes conflicting meanings that elite decision-makers possess about international education. Ultimately, it is argued that the discourse approach can offer both empirical insights and a range of policy recommendations from a discourse analysis that destabilises the dominant 'liberal' narrative about international education in the relevant documents.

\footnotetext{
${ }^{1}$ University of Nottingham, Nottingham NG7 2RD, UK. ${ }_{\text {email: ian.wash@nottingham.ac.uk }}$
} 


\section{Introduction}

s of 2015, the challenges confronting international education were such that 264 million children and young people were not in school, with $53 \%$ of the lower and upper-secondary school age group not receiving an education (UNESCO, 2017, p. 118). Damning though these statistics are, the dominance of the liberal doctrine remains virtually unquestioned by the bodies responsible for putting in place measures for change. This indicates a need to unpack the ideas and beliefs behind the liberal model and decode meanings to better understand why the efforts of international organisations and governments are off course. This article aims to explain the value of the discourse approach for interpreting the construction and resolution of policy dilemmas in the field of international education. Using case material drawn from official documents from 2000 to 2018, the article communicates the critical purpose of conducting discourse analysis and is driven by two motives. The first is empirical, the analysis revealing how a dominant liberal orthodoxy governing international education was discursively constructed as a grand narrative about the purpose and ideal outcomes behind international education. The second is methodological, arguing that in spite of criticisms of the discourse method as a form of public policy analysis and recognised limitations, the proposed approach can equip analysts with a reliable tool-kit for carrying out research which furthers understanding of how ideas inform policy practices in subtle but not well recognised ways.

This article makes an empirical contribution to research on public policy dilemmas. It uniquely constructs the taken for granted liberal model of international education as a grand narrative. The results are of importance since they uncover a conflicted version of reality that differs from the perceived harmony of the liberal deal and will speak to extant literature in the field. The findings also pick up trends of continuity and change, reflecting how the ebb and flow of ideational factors evolved the discourse over the arc of the narrative. Unmasking these complications and shifts may offer significant policy recommendations through its potential relevance on the impact side for communities of interest and international organisations. The contribution of this article is also methodological. It introduces the Interpretive Discourse Analysis (IDA) approach, specifically tailored to understanding the policy puzzle challenging international education in the promotion of national development in poorer countries. Applying the approach is significant because it questions the nature of positivist/empiricist mainstream policy research and its philosophical assumptions by demonstrating that the discourse approach provides a credible alternative for resolving policy dilemmas.

An interpretive approach to discourse analysis is introduced that combines two compatible variants in a way that enhances their capability to interpret policy dilemmas. This is applied to a range of policy documents and case-related texts systematically following six analytical steps. One argument made is that the liberal education model was discursively constructed as a narrative framework along three interlocking themes that follow the plot of a quest. In line with narrative theory, thematically arranging a set of events moving from vision to process and on to outcomes is amenable to narrativizing a 'completed story' (White, 1973 , p. 7). The narrative opens with the vision actors had for education leading to the process behind turning those aspirations into reality and concludes with the (un)intended and (un)desirable outcomes produced by the mechanisms in the education system. Importantly, this article argues that conducting an analysis of this type is a valuable means of understanding such policy dilemmas. This is explained by showing how the approach effectively unpacks theoretical dimensions, analytical strategies, and conflicting beliefs that expose the myth of a harmonious liberal model of international education.

The article is organised as follows. First, a review of the literature critiques positivist approaches to policy analysis and surveys previous discourse research on a range of public policy puzzles. Section "Literature review" presents the IDA approach and provides background on the case material used. Thirdly, extracts from the empirical data used in the analysis are presented and narrativised. Section "Results" provides an overview of the results of the analysis. This is followed by a discussion section reflecting on the value of the IDA approach and its limitations. The article concludes by summarising the value-added factors of the IDA and advancing its empirical and methodological implications for international education and the wider field of public policy analysis.

\section{Literature review}

Public policy analysis is viewed by the majority as a technical exercise and its practices are strongly influenced by economists. One example is Weimer and Vining's (2011, p. 344) rationalist model which begins with the analysis of a political problem followed by an assessment of possible solutions leading to the communication of policy recommendations. A key technique for evaluating possible solutions in mainstream policy research is cost-benefit analysis, which estimates the efficiency of public policies. It gained popularity in public policy through economists who consulted on water and flood projects in the US around the mid-20th century (Eckstein, 1958). Ever since, cost-benefit analysis has been applied to education and other areas of public policy by governments and institutions. Carneiro and Heckman (2003) apply cost-benefit analysis to calculate rates of return to education across all age groups in the US to conclude that the highest returns on investment occur in preschool programs. Similarly, Belfield (2009, p. 42) uses economic evaluation to argue that that investments in primary schooling are more efficient than those targeting secondary education. Such calculations have been used by researchers to convince policymakers to direct public spending into the earlier years education. Policy staff at the World Bank have also supported this practice when applied to education in developing countries (Psacharopoulos and Patrinos, 2002; Psacharopoulos, 1985). Diminishing social rates of return to education at the post-primary level provided sufficient justification for World Bank lending policy measures aimed at reducing public spending on higher education (Psacharopoulos and Woodhall, 1987, p. 55). However, measuring rates of returns and performing cost benefit analysis on education have proven to be controversial among development economists. For example, Bennell (1996) questions the relevance of using market-based indicators to analyse education in developing countries since schooling is not typically an economic input like any other.

Whereas mainstream policy analysts use quantitative methods to seek causal explanations of why education policies succeed or fail to improve schooling access and quality outcomes, interpretive discourse approaches analyse policy in terms of how elite beliefs sediment and come to shape education policy practices (Epstein, 2008; Wodak, 2001). As Bevir and Rhodes (2003, p. 3) point out, the weakness of positivist inquiries into public policy dilemmas is that they 'postulate given facts divorced from theoretical contexts as the basis of legitimate claims to knowledge'. Instead of arising from common laws, perceptions of truth and facts derive from theoretically informed beliefs. That being said, interpretive discourse approaches agree with the logic that a calculus of precise causality in policy analysis has a lower 
probability of generating understanding than an enquiry that explores representation and meaning (Milliken, 1999, p. 226).

Drawing on this interpretive turn in policy analysis (Epstein, 2013; Bevir and Daddow, 2015), discourse analysis has been deployed effectively to investigate a range of public policy dilemmas. Environmental studies have utilised discourse approaches to explore a range of topics: changes in dominant discourses in the international whaling debate (Epstein, 2008), shifts in contested meaning of ecological terms over time (Dryzek, 2005). Discourse on institutionalised racism has been analysed in various political contexts: racial categorisation through narratives in the US public administration system (Yanow, 2003), historically-rooted representations in racist and anti-Semitic discourses in Austrian politics (Wodak and Matouschek, 1993; Reisigl and Wodak, 2000), and negative framings of Muslims reproduced in the British media (Richardson, 2009). Another policy issue to profit from the discourse approach has been liberalism and the politics of New Labour: the discursive construction of 'Third Way' politics (Fairclough, 2000), and the performativity of Tony Blair's speeches on international security as maintaining Britain's geopolitical status as a hegemonic power (Fairclough, 2005). What each of these policy analysts share is an anti-positivist agenda critical of mainstream economic approaches to analysing policy. Observability in the physical world is rejected in favour of meaning, and meaning-making in the social sphere is paramount. Emphasis is firmly placed on the ways in which politics and policies unfold on the basis of actors' ideas and beliefs about the dilemmas they face and the policy levers they believe are best pulled to resolve them. This in turn relies on the stories elites tell themselves and each other about how to make things happen politically, and this is where discourse analysis comes into its own.

A more detailed examination of the value of the discourse approach can be illustrated through a review of the literature analysing Britain's relationship with the European Union. Daddow (2011) provides a narrative account of how Tony Blair and Gordon Brown struggled and ultimately failed to construct proEuropean norms against the backdrop of nationalist media coverage. Discourse analysis allowed the author to explain how New Labour's policy failures resulted from Eurosceptic social structures compounded by agential lapses of consistency in Blair and Brown's supposedly progressive discourse. Todd (2016) employs a post-structuralist discourse approach to analyse continuity and change in the UKs relationship with the mainland over a 40 -year period. Applying the discourse method revealed 'the mutually constituted nature of foreign policy and identity' and how concerns over British sovereignty had endured during the period whilst Euroscepticism had strengthened in the UK media (Todd, 2016 , p. 107). The value of the discourse approach in understanding the Britain-EU relationship can be understood by contrasting it with mainstream policy analysis on the dilemma. In a review of cost-benefit analysis studies calculating the impact of Brexit on British trade, Whyman and Petrescu (2017, p. 113) conclude that a withdrawal would lead to a reduction in UK-EU trade worth minus 2 to $3 \%$ of GDP depending on the negotiation of tariffs. However, this causal logic misses the meanings that have shaped Brexit Britain's trade policy. Zappettini (2019) reveals that beliefs over Britain as a powerful trading nation were behind argumentation over trade policy that was used to legitimise Brexit as a way of liberalising the UK economy and expanding trade agreements with the rest of the world.

The discourse approach is gradually becoming accepted as an analytical tool in research examining political issues in the field of education. As Ball (2013) demonstrates, one relevance of Foucault to education is the way his genealogical method lends itself amicably to interpretive analysis capable of exposing the historically embedded technologies of power in the British education system. Relevant to this article is the research on political reform in higher education that has benefitted from the discourse approach. Fairclough's (1993) analysis of UK higher education discourses identifies the construction of entrepreneurial identities that position universities within the broader social processes of marketisation and commodification. Similar studies on East Asian contexts indicate that this is part of a wider global trend of higher education aligning itself with free market values (Zhang and O'Halloran, 2013; Xiong, 2012). Of further relevance is the application of discursive approaches to studies of the Knowledgebased Economy (KBE). The economic dimensions of education are well-suited to interpretive discourse approaches since the $\mathrm{KBE}$ is perceived as a 'powerful economic imaginary' (Jessop, 2008 , p. 2). Fairclough and Wodak (2008) combine analytical approaches to expose the EU Bologna Process as a discursive means to drive higher education reform whilst promoting Europe as a modern KBE.

This article builds upon the work of discourse analysts who have investigated education dilemmas in the context of international development. Vavrus and Seghers (2010) interrogate the way that the term 'partnership' was used and abused in World Bank and International Monetary Fund participatory poverty reduction policies in Tanzania. The authors revealing how participant's opinions about ways to improve education and other public services were silenced by dominant neoliberal meanings of the term. McCormick (2012) shows how the norms of authoritative Education For All documents intertextually colonised thinking about education quality in Cambodia and Laos. The study uncovers how dominant institutional reports can override national ownership of international education in aid-receiving countries. Through a discourse analysis of the World Bank Education 2020 Strategy, Nordtveit (2012) discloses the underlying neoliberal beliefs of the organisation by exploring overly optimistic and hubristic representations of the future vision for the developing world. Seemingly innocuous and upbeat terms used in the strategy report were found to mask injustices and inequalities that shape the reality of student and parent lives in poorer countries.

This review of the literature indicates that interpretive discourse analysis provides a potent approach for understanding seemingly unsolvable puzzles in public policy and is suited to analysis of dilemmas in education. The IDA approach developed in this article draws on the interpretive-turn outlined above. The next section sets out the background to the case material and the article's analytical approach.

\section{Method}

IDA is a hybrid approach which synthesizes Yanow's (2000) Interpretive Policy Analysis (IPA) and Wodak's (2001) Discourse-historical approach (DHA). In IPA, reified aspects of discourse such as language, physical objects, and human actions are assumed to exist in a two-way relationship with meaning in the form of values, ideas, and beliefs (Yanow, 2000). In terms of production, when policy makers communicate their recommendations in reports or speeches, their text and talk is loaded with symbolic values and beliefs. There is a performative aspect to these communicative acts in that they are simultaneously both part of the policy process and producers of policy. The DHA is one of many approaches derived from Fairclough's (1992) Critical Discourse Analysis (CDA). Similarly, Wodak (2001, p. 66) shares the view that language and social practice have a dialectical relationship in that they constitute one another. However, the DHA develops CDA's three-dimensional model (text-discoursesocial practice) by analysing the context surrounding political 


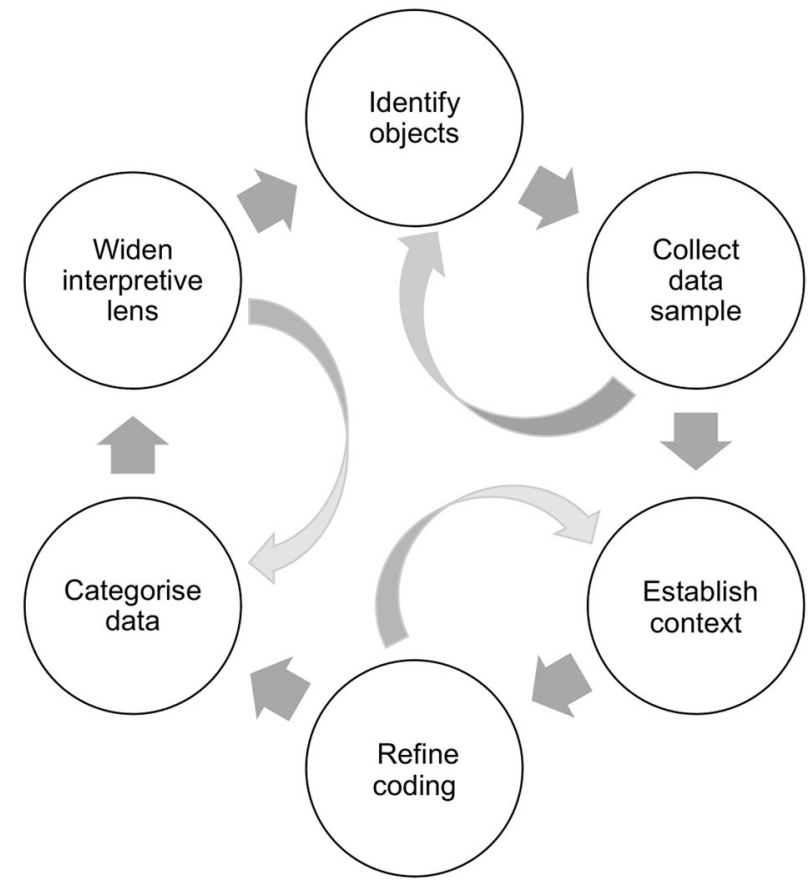

Fig. 1 The non-linear process of IDA. Visualises how the six stages of the analytical process are conducted in an iterative fashion.

puzzles and integrating these with interpretations of the discourse (Wodak, 2001, p. 67). In IPA, social context is considered prior knowledge and attention is focused on textual and discursive practice. By combining aspects of the DHA, relevant theories related to the policy issue can be elicited during analysis and the levels of text and discursive practice can be situated within the wider social, cultural and historical contexts surrounding the study (Wodak, 2001, p. 69). Another way the approaches complement one another is that they prioritise empathy over emancipation. They set out not to judge right from wrong but to make justifications based on theory and interpret why some public policy choices may be more acceptable than others.

As developed in this article, IDA combines procedural steps from both DHA and IPA. This approach considers discourse research as abductive, meaning it infers the most plausible explanations for phenomena. Because of this and the iterative nature of discourse analysis, these stages did not occur in a 'straight' linear order (see Fig. 1). There was as a constant 'to and fro' between observed language, textual meaning, contextual background and, ultimately, the interpretation of intended meaning. It is possible, however, to isolate the key stages in IDA as follows:

1. Locate the objects of research (e.g., language, ideas or actions) that contain, and are vehicles for, political meaning.

2. Collect a sample corpus of documents relevant to the objects of research. Determine the genre of texts and connections between other texts and discourses. Carry out a pilot study to establish a coding scheme.

3. Establish the wider context and identify communities of interest surrounding the policy issue. Formulate research questions and develop theoretical frameworks to explore these.

4. Refine coding and analyse the discourse by deploying appropriate interpretive tools such as argumentation, framing, and legitimation. Using the chosen theories, interpret meaning from discourse related to objects being investigated.

5. Categorise coded data into themes and topics that emerge in the discourse. Identify conflicts and divergences in meaning interpreted by communities of interest. Uncover plots and sub-plots in the story that evolved then interpret a grand narrative.

6. Widen the interpretive lens to make normative interventions. Clarify the implications of various meanings, empathetically demonstrate that diverse perspectives reflect different ways of viewing social reality, and then provide reconciliation to bridge differences.

The case material is drawn from official documents relating to international education policy from 2000 to 2018. Table 1 sets out the dimensions and contents of the corpus. Designing the corpus in such a way allows the power relations between the three levels to emerge during analysis.

Following an early review of literature which updated the analysts existing knowledge of policy debates in international education, a pilot study was conducted in which a small sample of documents were coded alongside an experienced political discourse analyst. The pilot study was geared towards improving the reliability of the study in two ways. Firstly, it verified that the IDA process described above was appropriate to the objects of study and the research questions being asked. The second purpose of the pilot study was to verify the reliability of the coding scheme and develop a framework to categorise the data. Once an initial coding scheme was in place and the context of the study began to take shape, a set of research questions came into view to guide the analytical process:

1. What kind of vision has driven the global education agenda since 2000 ?

2. How did agents discursively construct the management system governing education for international development?

3. What were the ideas behind the international education policies put into practice and the evaluations of policy outcomes?

Throughout the analytical process the coding strategy was refined to categorise the data. Table 2 shows how the analytical themes and topics evolved between the three phases of coding. This process involved ongoing revision of data categorisation into themes and topics, and the filtering-out of sub-plots and contextual items. For example, the KBE was a category of analysis in the pilot phase but became contextual in later phases as it featured across all themes and symbolised education in the postindustrial age. Further coding informed decisions to transfer, delete, replace, prioritise, and minimise categories as the process matured. Finally, themes took on storytelling significance and developed into a grand narrative that wove a thread through the discursive construction of the policy field covering vision, process, and, outcomes. Topics were grouped around binaries through which actors conceptualised each act of the narrative about the liberal deal in international education.

Using a thematic approach can lead to accusations of the analysis being too descriptive. However, as Todd (2016, pp. 22-23) rightly points out, presenting analysis by themes is justified when investigating broad and complex policy dilemmas. There are benefits in revealing how the narrative evolved in terms of themes being explored (e.g., vision, process, outcomes), the positions of actors (e.g., neoliberal, humanist), and the various framings that emerged (e.g., lifelong learning as second chance education). These phases in the evolution correspond to the 'what', 'who', and 'how' of the analysis, respectively. An additional merit of the thematic approach is that it reveals how the discourse 
Table 1 The international education corpus.

Level of corpus Type of documents

Approximate number of

documents

Core policy Reports from international organisations (mostly World Bank and UN agencies). Policy papers 100 and speeches from national governments

Intermediary Reports and policy briefings from the non-profit sector. Academic empirical literature

100

Periphery

News articles and transcripts of podcasts. Scripts from radio, television and film

100

Table 2 Evolution of analytical categories.

\begin{tabular}{|c|c|c|c|}
\hline & Pilot phase & Intermediate phase & Narrative phase \\
\hline RQ1 Topics & $\begin{array}{l}\text {-Economic benefits } \\
\text { - Social benefits } \\
\text {-Mission } \\
\text { - Inclusion } \\
\text { - Liberal state reproduction }\end{array}$ & $\begin{array}{l}\text { - Economic benefits } \\
\text { - Social benefits } \\
\text {-Ethical mission } \\
\text { - Inclusion } \\
\text { - State building }\end{array}$ & $\begin{array}{l}\text { - Economic prosperity } \\
\text { - Social progress } \\
\text { - Human development } \\
\text { - National security } \\
\text { - Inclusion }\end{array}$ \\
\hline RQ2 Topics & $\begin{array}{l}- \text { Value for money } \\
- \text { Partnerships } \\
\text {-Effectiveness } \\
\text {-Legislation } \\
\text {-KBE }\end{array}$ & $\begin{array}{l}\text {-Value for money } \\
\text {-Partnerships } \\
\text {-Effectiveness } \\
\text { - Legislation } \\
\text {-Accountability }\end{array}$ & $\begin{array}{l}- \text { Value for money } \\
\text {-Partnerships } \\
\text {-Evidence-based policy } \\
\text {-Measurement } \\
\text {-Accountability }\end{array}$ \\
\hline RQ3 Themes & $\begin{array}{l}\text { Global-national-local policy (plus uneven } \\
\text { resources) }\end{array}$ & Education policy results & $\begin{array}{l}\text { Outcomes (Binary: progressive realisation of education as a } \\
\text { human right/commodification) }\end{array}$ \\
\hline
\end{tabular}

evolved in terms of theories (e.g., human capital) addressed by categories. This explains the 'why' of the analysis.

Through establishing the context of the study and identifying interest groups, the theoretical framework for the analysis began to emerge. Each of the research questions connected to a theme which spoke to particular theoretical concern drawn out from the discourse on the liberal deal. The results of the analysis are followed by a discussion of how this theoretical framework informed the analysis. The next section presents a selection of coded extracts supported by a narrative commentary.

\section{Data}

Applying the IDA approach to the data revealed the how the actors, categories, representations, and theories contributed to the construction of the liberal model of international education as a grand narrative in three acts. Extracts from each theme are arranged using five theoretically informed topics around which the narrative unfolded. These are labelled according to the four ideological leanings that influenced the beliefs of institutions and individuals: neoliberal (N), liberal (L), anti-neoliberal (A) and humanist $(\mathrm{H})$.

Vision. The first theme explores the aspirations actors had for education. It speaks to a theoretical concern about the influence of human capital, defined as income earned or economic growth derived from investment in the skills and knowledge of individuals (Woodhall, 2001, p. 6951). Figure 2 presents the five topics that comprise the vision. These topics emerged from a mid-level

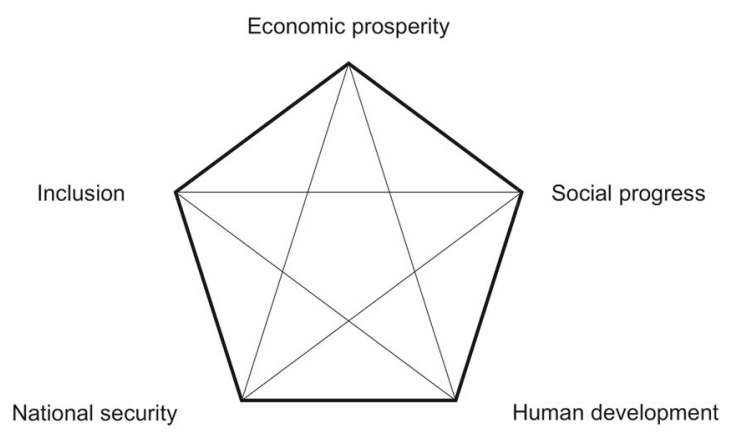

Fig. 2 The vision. Illustrates the topical categories that discursively constructed the vision of the liberal education narrative.

theoretical debate concerning whether education was an economic good or a social good.

Economic prosperity was the most significant part of the vision of education, perceived as a means to guarantee the wealth of individuals and nations. In extract 1, human capital logic spread intertextually through rates of return statistics resulting in liberal discourses such as the UNESCO Education for All Global Monitoring Reports echoing the beliefs of World Bank economists Psacharopoulos and Patrinos (2004). Representations of education as socialisation (extract 2) advanced by rights-based beliefs challenged the economic logic that framed social progress through the development of employability and transferrable skills. The influence of representations of the vision of education as human development owed much to the impact of Amartya Sen's 


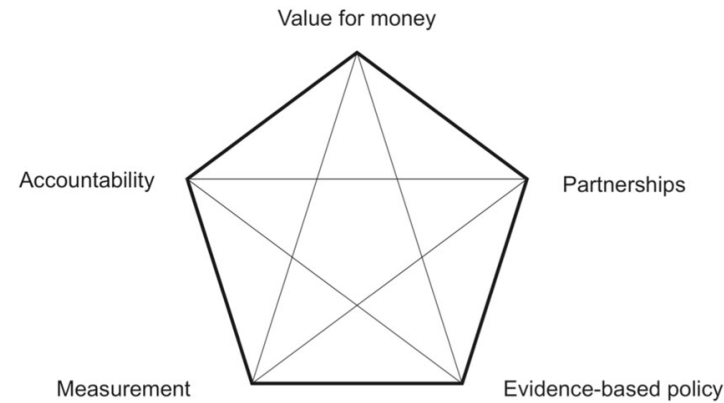

Fig. 3 The process. Illustrates the topical categories that discursively constructed the process of the liberal education narrative.

(1999) human capabilities model on UNESCO (extract 3) and other institutions. This occurred in the context of human rights mainstreaming following the 1997 UN Programme of Reform which gradually undermined human capital theory. With the War on Terror in the background, authoritative framings of education as a means of escaping a conflict-trap through raising incomes (extract 4) proposed by leading development economist Paul Collier were influential. Framings of education as social integration and readiness to work inspired by late-1990s New Labour rhetoric on social exclusion were dominant in donor education policies that reinforced the neoliberal workfare agenda (extract 5).

1. One standard deviation increase in test scores was associated with wage increases ranging from $12 \%$ to $48 \%$, suggesting a substantial return to higher levels of cognitive skills (UNESCO, 2005, p. 41). [N]

2. The right to develop one's personality, talents and abilities to their fullest potential (UNICEF, 2009, p. 4). [H]

3. Education counts as a 'valuable being or doing', as an 'end' of development (UNESCO, 2002, p. 32). [L]

4. If the male secondary school enrolment rate is 10 percentage points higher than the average, the risk of war is reduced by about four percentage points (Collier and Hoeffler, 2000, p. 23). [N]

5. A successful transition to work for today's many young people can accelerate poverty reduction through better allocation of their labour, and boost economic growth (World Bank, 2007, p. 96). [N]

Process. Exploring how the vision was made use of involves analysing the most significant parts of the process driving the management of international education. The theory of New Public Management (NPM) emerged as a site of contestation in the process. NPM refers to a set of ideas replacing traditional bureaucracy in which the state is run according to the principles of managerialism, professionalism, and entrepreneurialism (Hood, 1991). Figure 3 illustrates the categories that discursively constructed the process. Informing these topics was a mid-range theoretical dispute between actors whose interests in the process leant towards marketisation or humanisation.

Ongoing debates over aid effectiveness intensified by the 2008 global financial crisis elevated value for money as the most important part of the education management system. 'Smart investment' rhetoric in the World Bank's Education Sector Strategy 2020 (extract 6) echoed the 'Third Way' philosophy of New Labour and its obsession with fiscal prudence. In extract 7 , supporters of choice and competition represented the growing role of business in public schooling as partnerships to insulate themselves from anti-neoliberal suspicions over the state selling out education. Scientific approaches using empirical evidence to

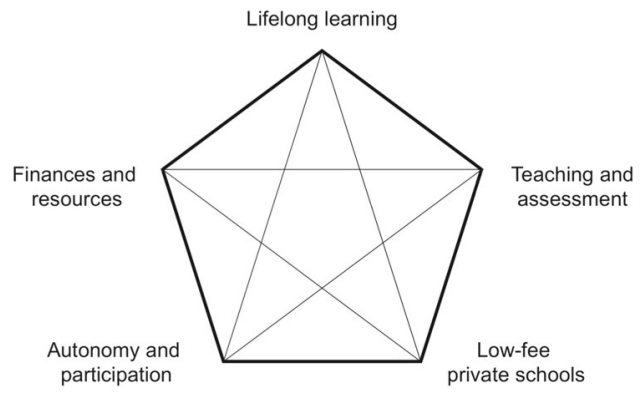

Fig. 4 The outcomes. Illustrates the topical categories that discursively constructed the outcomes of the liberal education narrative.

determine and promote best practice were a bone of contention in the process. Sceptics represented evidence-based policy as a cloaking device to push through reforms based on capitalist values (extract 8 ). The rise of education management information systems were depicted as tools of the managerial trend towards 'metricisation' and part of a wider tyranny of numbers in public policy (extract 9). In the climate of monitoring and neoliberal concern over state inefficiency, the expert authority of private school advocates powerfully represented accountability as a benefit of market reform in education (extract 10). Rivals framings countered with claims over accountability as a driver of marketisation and affirmations of the state as ultimate dutybearer of the right to education.

6. Getting value for the education dollar requires smart investments-that is, investments that have proven to contribute to learning (World Bank, 2011, p. 4). [N]

7. Partnerships are not privatisation, which involves the permanent transfer of control from a public agency to one or more private parties (Latham, 2009, p. 2). [N]

8. If we consider the weight of evidence, education policy appears not to have been driven by 'what works', but rather to have been driven by an almost dogmatic approach that has consistently overvalued the contribution of the private sector and undervalued the public sector (Farnsworth, 2010, p. 60). [A]

9. Measurement and monitoring as techniques for reflection and representation play a particular role within the contemporary relationship between truth and power and the self that we call neoliberalism (Ball, 2015, p. 299). [A]

10. For policy-makers, contracting represents an effective means for introducing accountability in the education system (Patrinos and LaRocque, 2007). [N]

Outcomes. The final theme aims not to evaluate the education policies implemented themselves but to explore what politicians thought they were doing by making particular policy decisions and to analyse beliefs behind policy evaluations. It addresses actor's concerns over the theory of uneven and combined development. In other words, that the spread of capitalism across the world throughout history did not occur uniformly but rather adoption was staggered in terms of dates and form altered by the culture and societal conditions of the settings it arrived in (Rosenberg, 1996, p. 6). Figure 4 presents a pentagram of the five categories. These topics emerged from a mid-level theoretical debate concerning whether policy outcomes reflected the commodification of education or the progressive realisation of the right to education.

Lifelong Learning was believed to be the most significant policy outcome from 2000 onwards. The original liberal conception was commodified during the period by pro-market framings that 


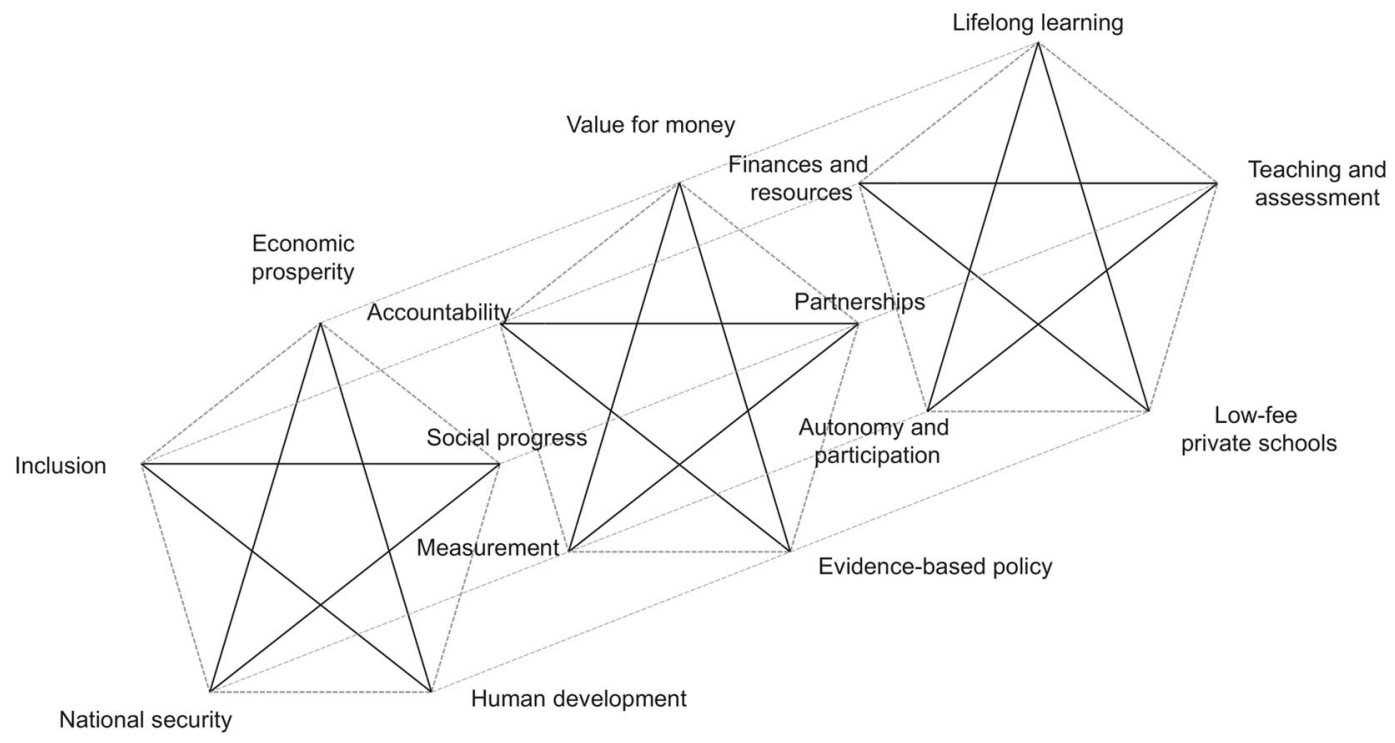

Fig. 5 Meta-pentagram of the Grand Narrative. Illustrates how the three thematic pentagrams connect together to form a grand narrative.

arranged learners into customer demographics (extract 11). Framed as a second chance to top-up skills and knowledge, rival beliefs interpreted this as a threat to formal education. Norms over quality teaching as delivered in a medium that equips learners to thrive in the economy clashed with values driving instruction in minority languages that was argued to be more progressive towards attainment of the right to education (extract 12). Representations of low-fee private schools as cutting edge and equitable provision (extract 13) from opinion leaders such as James Tooley backed International Finance Corporation policy to support Bridge International and other private providers. Extract 14 shows how neoliberal beliefs on school autonomy and parent participation were challenged by resistant narratives highlighting the inherent contradiction of empowering central government. Humanist readings of participation as exercising civil and political rights through school decision-making also contributed to this. Evaluations of philanthropy surged in the context of austerity following the financial crisis. For example, the entrepreneurial values driving Mastercard's charitable giving (extract 15) conflicted with ethical arguments over dependency and the public interest.

11. Firms can no longer rely solely on new graduates or new labour market entrants as the primary source of new skills and knowledge. Instead, they need workers who are willing and able to update their skills throughout their lifetimes (World Bank, 2003, p. xviii). [N]

12. Teachers make full use of Mayan languages and culture that have in the past been marginalised despite their importance to half the country's population. The result is a completion rate above the national average and a high enrolment rate for girls (UNICEF, 2004, p. 1). [H]

13. Private education companies respond to the needs of the disadvantaged by provision of innovative social responsibility programmes, subsidised places and student loan schemes (Tooley, 1999, p. 16). [N]

14. The reality is that devolution and choice are occurring as part of a broader political strategy. Certainly, the recent education reforms in Britain have as much to do with transferring power to central government as with giving autonomy to parents and schools (Whitty, 1997, p. 36). [A]

15. Through its collaboration with committed partners, The MasterCard Foundation is increasing access to microfinance and youth education, helping people living in poverty to learn and prosper (Mastercard Foundation, 2011). [N]

\section{Results}

Drawing on the data presented, this section gives a brief overview of the results. Firstly, a summary of the narrative and critical aspects of the analysis is provided. Secondly, an overview of the key continuities and changes in the discourse will be presented.

To summarise, the dominant liberal model governing international education between 2000 and 2018 was discursively constructed as a grand narrative about the purpose and intended outcomes in international education. The overall plot was mapped out as a quest in which a diverse party of actors armed with a conflicted vision for education negotiated obstacles and difficulties on a political journey, hopeful for a desirable outcome (see Fig. 5). The aspirations, mechanisms and outcomes of the liberal education model were continually in dispute throughout the narrative. They were sites of tension for institutions and individual actors whose beliefs were underpinned by (anti-)neoliberal, liberal, or humanist ideologies. These positions shaped individual narratives, decisions and subsequently their political actions. Cleavages occurred because actors clashed over the theories of capitalism (e.g., NPM) around which the themes of the narrative emerged. For instance, Katarina Tomaševski and other humanistleaning actors fought to discredit NPM by convincing others that all parts of the process existed to serve human needs rather than markets. The manner of this conflict unfolded in the way that actors represented and prioritised elements of each theme according to their positions in a series of mid-level theoretical debates. For instance, the UK Department for International Development and the World Bank maintained NPM as the dominant theory to guide processes in education by representing value for money as a top priority. Framing this through arguments based on efficient use of tax and effective aid spending reflected a positive appreciation of the marketisation of education.

There were a number of key continuities and changes that came to light in the international discourse on education for development. Two significant aspects of continuity can be identified. First, the importance of technology as a consistent sub-plot running through the grand narrative. This may not come as a surprise given the complementary relationship 


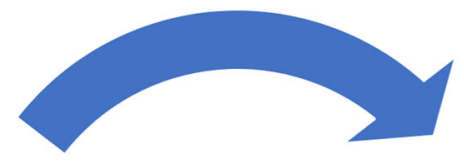

VISION

Education as an asset

KBE

OUTCOMES

Education as products/ services

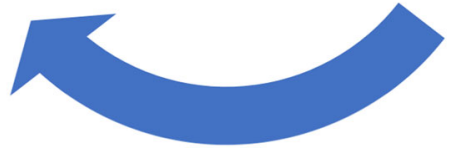

Fig. 6 KBE interdependency model. Illustrates how aspects of the knowledge-based economy in the vision and outcomes had an interdependent relationship throughout the grand narrative.

between technological advancement and classical liberalism. However, the role of IT was constantly being negotiated in the vision (e.g., the relevance of traditional skills), the process (e.g., data management systems), and outcomes (e.g., marketing of online learning services in poorer countries). Second, the constant relevance of the $\mathrm{KBE}$ as a contextual factor in the grand narrative that manufactured consent over capitalist theories. Its multi-faceted nature placed the $\mathrm{KBE}$ as a central point of interdependency linking outcomes with aspirations in a symbiotic relationship (see Fig. 6). Modern skills and knowledge were assets that allowed individuals to participate and thrive in the post-industrial economy. This aspect of the KBE simultaneously supplied the skilled labour necessary to develop innovative educational products and services (mostly produced in wealthy Western countries) whilst generating demand for them.

There are two main changes from the narrative to highlight. First, the processes in the management of the education system continued to grow in significance relative to the outcomes. Whereas the conventional wisdom of strategic planning points to processes driving outcomes, the grand narrative illustrates a shift in the way that outcomes contributed and were subordinate to managerial processes. In many ways, the liberal objective of raising standards was advancing the process of privatisation and decentralisation central to the administration. For example, the establishment of low-fee private schools was dependent on the process of facilitating private sector involvement in education provision by promoting partnerships between edu-businesses and the state. Second, there was a gradual weakening of the dominance of human capital theory in the vision act of the narrative. Beliefs driven by anti-neoliberal and humanist ideologies succeeded in eroding the dominant aspiration for economic prosperity through argumentation that better articulated the case for education as a social good. To highlight an example, representation of human development as the fundamental purpose of education was legitimised by the scientific rationalisation of the capabilities approach combined with the impersonal authority of the UN International Covenant on Economic, Social and Cultural Rights.

\section{Discussion}

In reference to the data and results presented, this section reflects on discourse as a method. It seeks to answer the following questions: What do the case study data and results tell us about discourse analysis? How does a discourse analyst make sense of what's going on? Following that, the limitations and proposed weaknesses of using discursive approaches in public policy analysis will also be explored. The section concludes by reflecting on specific ways in which the discourse approach advances empirical knowledge on public policy issues in the sphere of education.

Making sense of political theory and case data. Avoiding conventional modes of enquiry that follow deductive or inductive logic, IDA views the relationship between theory and data as abductive. In other words, interpretations are based on explanations that make the most sense. This study began with the identification of an a puzzle concerning the dominance of liberal ideas about international education and drew upon intermediate theories that provided resolution by explaining patterns in the data (Peirce, 1998, p. 106). It is necessary to clarify the connections between the analytical approach and the theories that provide reasoning but these are unknown at first and gain focus during the analytical process. The discourse analyst works iteratively in a back-and-forth style moving between empirical data and theory, until the process generates theories that initially informed the researcher's expectations of what they thought the political reality was (Schwartz-Shea and Yanow, 2012, p. 28). It is also worth noting that when presenting discourse analysis on public policy, it is not necessary to have a clear delineation between theory and case study data. As Epstein (2008, p. 9) puts it, 'the theory is woven into the analysis of the case itself. This integration of the theoretical and the empirical serves to justify the inclusion of chosen theories to conventional political researchers since removing it would seriously diminish the analysis.

This analysis was informed by a two-tier model of grand and middle-range theories which formed the context of the liberal narrative. The three analytical themes which addressed each of the research questions spoke to theoretical concerns over a trio of capitalist theories. Each contributed to the discursive construction of the liberal education model riven by conflicted norms and disharmony. Once the grand theoretical framework was in place and the underlying assumptions were understood, theory worked to develop sub-categories of data (Wodak and Weiss, 2005, p. 125). Operating beneath the main framework were a range of lower-level theories that served the analysis by directing the coding of topics and interpretation of binaries. Firstly, the vision theme was guided by meso-theories about education as a social or economic good. Actors who believed in education investment decisions based on economic approaches were challenged by rival beliefs in education as a social good delivering public benefits beyond higher incomes or GDP growth. In the process theme, mid-level theories about marketisation and humanisation informed the analysis. Beliefs leaning towards humanist and anti-neoliberal ideologies struggled to weaken the dominance of managerial norms driving the entrepreneurial processes of costcutting, monitoring, and unleashing market forces. Finally, the outcomes were directed by intermediate theories concerning the extent to which education had become a commodity and whether the progressive realisation of education as a human right had been advanced. The beliefs of those in support of the full achievement and enjoyment of the right to education were challenged by actors who valued the competitive marketplace of educational goods and services. In sum, while the interplay of the grand theories shaped the disharmony in the overall narrative, meso-theories elicited the topics and binaries which brought out power relations in the discourse. Textual analysis contributed to this through coding for argumentation to reveal the tensions which formed conflicting narratives.

Drawing out tensions, arguments, and contradictions through coding. As the coding strategy matured and was confirmed by the categories, various tensions, arguments, contradictions, and 
concessions were teased out through the analysis. As Epstein (2008, p. 12) points out, the key modality of political reality is conflict rather than cooperation and ruptures of change determine history to a greater extent than continuities brought about by agreement. Making sense of these decoded tensions requires analysis at the textual level to investigate language in use. Again, this is a customised exercise rather than a one-size-fits all solution since the choice of analytical tools depends very much of the specific social or political issue under investigation. The discursive strategies most relevant to analysing the liberal deal in international education were legitimation and argumentation. Both were used to reinforce the beliefs of agents and they also combined to support the construction of narratives within and between categories.

Legitimation is one way of representing or framing political reality. It is the representation of political ideas that determines how actors make sense of policy discourse and interpret meaning. Legitimations supplement representations of political practices by adding extra elements to the framing (van Leeuwen and Wodak, 1999). When actors legitimise or delegitimise political practices they foreground certain clues, validate beliefs, and reinforce ideas. Legitimation of policy choices is particularly salient to the field of international education policy because rival actors vie to validate their decisions based on moral or logical positions. One type of legitimation that was powerful in the analysis was authorisation. By using personal, expert, or role model status, political figures in positions of power were able to legitimise education policy practices. An example of personal authority in the case material would be the various ways in which Gordon Brown shaped the liberal education model, in his roles as Blair's Chancellor of the Exchequer, Prime Minister and later on as United Nations Special Envoy for Global Education.

Whereas legitimation works more to defend entrenched beliefs in discourse, argumentation goes on the offensive to change them. On the one hand argumentation persuades others that a course of action is best based on certain values or norms, and on the other it challenges the beliefs of others (Finlayson, 2007). Analysing argumentation strategies in the discourse allows interpretive researchers to reveal how political actors provide reasoning for their actions. As a practical analytical tool, various argumentation categories can usefully identify rhetorical sub-types and connect arguments to their conclusions (Kienpointner and Kindt, 1997, p. 562). For example, one of Wodak's (2001, pp. 73-77) argumentation types analyses rhetoric based on numbers. This 'topoi', to borrow Wodak's terminology, follows the characteristic that if the numbers prove a specific argument, a specific action should be performed or not be carried out. An example from the case data would be how the rhetoric of numbers was used in evidencebased policymaking to globally promote voucher schemes and low-fee private schools using limited data from the two schemes in Colombia.

When actors legitimise ideas or construct arguments in the case material they are also generating narratives. Narratives are essentially representations in and of themselves (Riessman, 1993, p. 2). They form an integral part of doing discourse analysis on public policy as they simultaneously shape, create, and become sources of meaning (Yanow, 2000, p. 58). Meanings created through narratives are actionable and performative in nature. This is because the beliefs of agents are drivers of their actions and desires making narratives a form of explanation for the policies that are acted out in the real world (Bevir, 2006, p. 285). One narrative that emerged from the case material on processes was that the private sector could provide innovative solutions to improve education provision to the poor through PPPs. This chronicle of private sector as savior was opposed by a counternarrative rejecting the way in which corporations were replacing states as core providers of education. In addition, legislation appeared from the analysis as a fascinating sub-plot in the processes driving the liberal education model. Legislation flowed through themes and topics in several ways. Firstly, attempts to legitimise education as a marketable good or service like any other were strengthened by World Trade Organisation reports that negotiated the terms and conditions of the education market. On the other hand, advocates of a humanistic approach to education used rights treaties and conventions to generate the narrative that the right to education was enshrined and to be protected. In sum, narrative modes of explanation together with legitimation and argumentation strategies are all considerable assets of IDA. However, the approach is not without its limits and vulnerabilities.

Critical reflection on limitations and weaknesses of IDA. This section will critically reflect on two possible sets of critique of the IDA approach laid out in this article. Firstly, criticisms of interpretive methods from quantitative perspectives will be addressed. Secondly, internal critiques of critical forms of discourse analysis from other variants of the discourse method will be presented and responded to.

One major limitation faced by discourse analysts of public policy is having positivist criteria that they ultimately reject brought to bear on them (Yanow, 2006, p. 9). Being held to account by traditional definitions of validity guarantees that interpretive policy research fails the test before it has even begun. Research judged as unfaithful to the positivist paradigm and straying from the benchmarks for generating and testing theory in the quest for knowledge is considered insufficiently robust (Turner, 1985). This limitation has been addressed by interpretive researchers. Aware that their research can not and should not be judged in full by the standards of quantitative methods due to differences in their epistemological and ontological beliefs, a set of evaluative standards were drawn up based on the overarching principle of 'trustworthiness' in interpretive research (Guba, 1981; Lincoln and Guba, 1985).

Lincoln and Guba (1985) present a revised set of evaluative standards that enable interpretive work to be judged on equivalent lines to positivist research and provide techniques for meeting various standards. As an alternative to internal validity in mainstream research, credibility seeks to check the inherent value of analysis. This is done in the understanding that analysts agree that reality is socially constructed. One technique for insuring credibility is prolonged engagement, wherein researchers expose themselves to the issues being studied for an extended period of time. This is achieved through time spent academically engaged in the policy field and immersion in the relevant literature. Acting as an alternative to external validity used in mainstream enquiry, transferability keeps a check on the level to which conclusions drawn from analysis can be generalisable. One technique to improve the transferability of interpretive research comes in the form of thick description (Geertz, 1973). Approaches such as IPA and DHA embrace thick description which is achieved through 'a nuanced portrait of the cultural layers that inform the researcher's interpretation of interactions and events' (Schwatz-Shea, 2006, p. 101). The principle of reliability is substituted with the standard of dependability and seeks to discover whether similar results would be produced if the same research design were repeated under similar conditions. Lincoln and Guba (1985, p. 317) suggest 'stepwise replication' as one way of boosting dependability. This technique can be implemented during a coding pilot study with a co-analyst to check for inter-coder reliability. Another way involves fellow discourse analysts reviewing each other's research 
to pass judgement on whether it is up to standard, suggesting refinements, modifications, and improvements where necessary (Howarth, 2000, p. 142). Finally, the standard of confirmability acts as an equivalent to objectivity which focuses more on the data than the role of the researcher. Confirmability can be boosted through practicing reflexivity in social research wherein analysts reflect critically on their interpretations (Bourdieu and Wacquant, 1992). One reflexive technique suggested by Lincoln and Guba (1985, p. 319) is the audit trail. This entails keeping meticulous records of everything produced in the analytical process such as field notes, coded documents, mindmaps, and drafts of written analysis.

Critical forms of discourse analysis also faced challenge from within the discursive research community as variants vied for credibility. The validity of CDA has been criticised for being impressionistic. In other words, it is overly subjective and unsystematic. Analysts using variants of CDA were challenged for their lack of systematic rigour and for failing to be sufficiently explicit about analytical procedures (Stubbs, 1997). The objectivity of CDA approaches were also placed under scrutiny for the role that the investigator plays during analysis. Analysts were accused of producing biased research in which prejudicial analysts discovered traces of ideologies they actually set out to find within a text (Widdowson, 1995; Slembrouck, 2001).

Both criticisms were targeted at earlier critical discourse research. The first wave, much of which was influenced by Faircloughian CDA, was heavily Marxist and radical its approach. Its idealism exposed analysis to claims of impressionism and political bias. The second wave of discourse analysis responded to critics with systematic upgrades. One way in which analysts systematised their research was by providing procedures for conducting particular approaches. The CDA method moved beyond general guidelines to guide analysis by suggesting a more systematic procedure for analysts (Fairclough, 2003). Others created comprehensive toolkits with instructions on how to carry out discourse analysis (Gee, 2011). Discourse analysts in the field of foreign policy became transparent about their coding practices by clearly presenting coding lists and providing examples of coded texts (Daddow, 2011). The analytical process reflected on in this article builds upon these systematic upgrades to provide a reliable method. Finally, updated approaches also tackled charges of impressionism. This was partly achieved by taking up less radical positions than earlier emancipatory analysts and aiming for a more empathetic analysis (Wodak, 2001; Yanow, 2000). Being empathetic to the ideas and motives of human actors was important for the analyst when working with the case material since taking an anti-neoliberal or pro-human rights position would have cast doubt on the credibility of the study. Furthermore, an emancipatory stance would compromise the empirical implications of the study as a route towards arbitration. Empathy on the part of the analyst preserves a valuable asset of the discourse method: its potential to produce empirical findings that advance our knowledge of public policy issues.

Producing empirical evidence to develop understanding of public policy issues. By evolving and customising discursive approaches, analysts are able to advance empirical knowledge and take steps towards resolving seemingly intractable public policy dilemmas. This is particularly true of analysis that takes education issues as its object. As the case study has shown, empirical insights were gained from applying the IDA approach that destabilised the dominant liberal narrative about international education. Explaining how the liberal model was constructed as a grand narrative about the vision, process and outcomes in international education revealed aspects of continuity and change embedded in the discourse. For example, an IT sub-plot pervaded the narrative that prioritised competencies and skills to thrive in the post-industrial workforce, management through data monitoring and information systems, and commercial online learning packages. In addition, the KBE endured as a powerful discursive imaginary which legitimised consent for education as an interconnected cycle of economic assets and commodities. One element of change that emerged concerns how the management system governing international education gradually took precedence over outcomes. This discursive shift reflects the way in which public management norms were internalised in the field, allowing the dynamics of marketisation to gain dominance whilst the effects of practical policies were subtly cast aside as a secondary consideration. Another aspect of change embedded in the discourse was the gradual abating of human capital as a dominant theory driving the vision, shaped by the beliefs of actors who challenged the economising logic of neoliberal aspirations.

As Schulze-Cleven et al. (2017) concur, interpretive research that detects subtle sociopolitical shifts in education is vital for developing our knowledge of fundamental challenges and sharpening our awareness of how the forces of capitalism can be shaped by ideational factors. The authors identify similar trends in studies of higher education as those garnered from the case material. For instance, the way that neoliberal actors such as Western governments and international institutions have forged ever closer links between public education and the market economy. Another example is the reliance on measurement in the governance of education through monitoring, data collection, benchmarking, and systematic evaluation. These trends can be perceived as the 'new technology of discursively mediated power' (Schulze-Cleven et al., 2017, p. 803). Angermuller's (2017) study into the identities and careers of academics furthers our understanding of this discursive interplay between the market and education. His analysis reveals how academics inhabiting institutional systems in economies based around enterprise capitalism are subject to market forms of valuation and selfdefinition. Careers in these settings reflect and are constrained by market factors such as wider income gaps and weaker job security. These findings are relevant to those of the present case study since they indicate ways in which the forces of marketisation may be shaping education practices. In these studies, discourse analysis furthers our understanding and provides a solid empirical platform to begin thinking about how to resolve such public policy dilemmas.

\section{Conclusion}

IDA provides a valuable approach for understanding the discursive construction of education in the promotion of international development. Applying the analytical steps to the international education corpus exposed how the dominant liberal model governing the field was constructed as a three-act grand narrative. Reflecting on the how the analyst made sense of the data revealed deep-rooted tensions and contradictions hidden beneath the surface of coded extracts. For the real value of conducting discourse analysis on policy issues is elucidated when friction shaped by embedded theories is laid bare, arguments and legitimations are decoded, and conflicting dynamics such as binaries concealed within the narrative framework are revealed. As mentioned, weaknesses and limitations of discourse analysis can be overcome through continually upgrading the approach to make the analytical processes more systematic and transparent. Furthermore, the discourse approach produces empirical evidence that progresses understanding about public policy dilemmas, especially those in the field of education. 
The added-value of conducting IDA on public policy puzzles has various empirical and methodological implications. Firstly, unmasking such tensions enables the analyst to offer significant policy recommendations previously obscured by, in this case, the dominance of the liberal education narrative. Analytical findings can chart a course to resolution in reconciling differences and preparing a fully-functional policy environment. Secondly, the practical analytical tool-kit outlined in this article could be deployed to investigate other dilemmas in the fields of public or foreign policy. Applying the analytical steps and flexibly adapting the approach to other political issues offers analysts a credible alternative to mainstream positivist methods that dominate policy analysis.

\section{Data availability}

All data generated or analysed during this study are included in this published article.

Received: 13 November 2019; Accepted: 3 September 2020;

Published online: 21 October 2020

\section{References}

Angermuller J (2017) Academic careers and the valuation of academics. A discursive perspective on status categories and academic salaries in France as compared to the U.S., Germany and Great Britain. Higher Educ 73:963-980

Ball SJ (2013) Foucault, power, and education. Routledge, New York

Ball SJ (2015) Education, governance and the tyranny of numbers. J Ed Pol 30 (3):299-301

Belfield CR (2009) Elementary and secondary schooling. In:Weimer DL, Vining AR(eds) Investing in the disadvantaged: assessing the benefits and costs of social policies. Georgetown University Press, Washington DC, pp. 31-48

Bennell P (1996) Rates of return to education: does the conventional pattern prevail in Sub-Saharan Africa? Wld Devt 24(1):183-199

Bevir M (2006) How narratives explain. In: Yanow D, Schwartz-Shea P (eds) Interpretation and method: empirical research method and the interpretive turn. Sharpe, New York, pp. 281-290

Bevir M, Daddow O (2015) Interpreting foreign policy: national, comparative and regional studies. Int Rel 29(3):273-287

Bevir M, Rhodes RAW (2003) Interpreting British governance. Routledge, London

Bourdieu P, Wacquant L (1992) An invitation to refexive sociology. Polity Press, Cambridge

Carneiro P, Heckman JJ (2003) Human capital policy. In: Heckman JJ, Krueger AB, Friedman BM (eds) Inequality in America: what role for human capital policies? MIT Press, Cambridge, pp. 77-240

Collier P, Hoeffler A (2000) Greed and Grievance in Civil War. World Bank. http:// documents.worldbank.org/curated/en/359271468739530199/Greed-andgrievance-in-civil-war. Accessed 17 March 2020

Daddow O (2011) New labour and the European union: Blair and Brown's logic of history. Manchester University Press, Manchester

Dryzek J (2005) The politics of the earth: environmental discourses. Oxford University Press, New York

Eckstein O (1958) Water resource development: the economics of project evaluation. Harvard University Press, Cambridge

Epstein C (2008) Power of words in international relations: birth of an anti-whaling discourse. MIT Press, Cambridge

Epstein C (2013) Constructivism or the eternal return of universals in International Relations. Why returning to language is vital to prolonging the owl's flight. Euro J Int Rel 19(3):499-519

Fairclough N (1992) Discourse and social change. Polity Press, Cambridge

Fairclough N (1993) Critical discourse analysis and the marketisation of public discourse: the universities. Disc Soc 4(2):133-168

Fairclough N (2000) New labour, new language? Routledge, London

Fairclough N (2003) Analysing discourse: textual analysis for social research. Routledge, London

Fairclough N (2005) Blair's contribution to elaborating a new 'doctrine of international community'. J Lang Pol 4(1):41-63

Fairclough N, Wodak R (2008) The Bologna process and the knowledge based economy. In: Jessop R, Fairclough N, Wodak R (eds) Eduction and the knowledgebased economy in Europe. Sense Publishers, Amsterdam, pp. 109-125

Farnsworth K (2010) Education, education, education or business, business, business? In: Green A (ed) Blair's educational legacy: thirteen years of new labour. Palgrave Macmillan, New York, pp. 45-64
Finlayson A (2007) From beliefs to arguments: interpretive methodology and rhetorical political analysis. Brit J Pol Int Rel 9(4):545-563

Gee JP (2011) How to do discourse analysis: a toolkit. Routledge, New York

Geertz C (1973) Interpretation of cultures: selected essays. Basic Books, New York

Guba EG (1981) Criteria for assessing the trustworthiness of naturalistic inquiries. Ed Tech Res Devt 29(2):75-91

Howarth D (2000) Discourse. Open University Press, Buckingham

Hood C (1991) A public managment for all seasons? Pub Admin 69(1):3-19

Jessop B (2008) Introduction. In:Jessop B, Fairclough N, Wodak R (eds) Education and the knowledge-based economy in Europe. Sense Publishers, Amsterdam, pp. 1-9

Kienpointner M, Kindt W (1997) On the problem of bias in political argumentation: an investigation into discussions about political asylum in Germany and Austria. J Prag 7:555-585

Latham M (2009) Public-private partnerships in education. EdInvest, Washington DC

Lincoln YS, Guba EG (1985) Naturalistic inquiry. SAGE Publications, Beverly Hills

Mastercard Foundation (2011) Equity group foundation and the mastercard foundation launch the largest secondary education scholarship program in Kenya. Mastercard Foundation. http://www.mastercardfdn.org/equity-groupfoundation-and-the-mastercard-foundation-launch-the-largest-secondaryeducation-scholarship-program-in-kenya/. Accessed 21 May 2018

McCormick A (2012) Whose education policies in aid-receiving countries? A critical discourse analysis of quality and normative transfer through Cambodia and Laos. Comp Ed Rev 56(1):18-47

Milliken J (1999) The study of discourse in international relations: a critique of research and methods. Euro J Int Rel 5(2):225-254

Nordtveit BH (2012) World Bank Poetry: How the Education Strategy 2020 Imagines the World. In:Klees SJ, Samoff J, Stromquist NP (eds) The World Bank and education: critiques and alternatives. Sense Publishers, Rotterdam, pp. 21-32

Patrinos H, LaRocque N (2007) Enhancing accountability in schools: what can choice and contracting contribute. World Bank. http://documents.worldbank org/curated/en/275321468339552387/Enhancing-accountability-in-schoolswhat-can-choice-and-contracting-contribute. Accessed 27 Sep 2017

Peirce CS (1998) The essential peirce: selected philosophical writings. Indiana University Press, Bloomington

Psacharopoulos G (1985) Returns to investment in education: a global update. Wld Devt 22(9):1325-1343

Psacharopoulos G, Patrinos HA (2002) Returns to investment in education: a further update. World Bank, Washington DC

Psacharopoulos G, Patrinos HA (2004) Returns to investment in education: a further update. Ed Econ 12(2):111-134

Psacharopoulos G, Woodhall M (1987) Education for development: an analysis of investment choices. World Bank, New York

Reisigl M, Wodak R (2000) Austria-first: a discourse-historical analysis of the Austrian "Anti-Foreigner Petition" in 1992 and 1993. In: Reisigl M, Wodak R (eds) The semiotics of racism. Passagen Verlag, Vienna, pp. 269-303

Richardson JE (2009) 'Get shot of the lot of them': election reporting of Muslims in British newspapers. Patt Prej 43(3-4):355-377

Riessman CK (1993) Narrative analysis. SAGE, London

Rosenberg J (1996) Isaac Deutscher and the lost history of international relations. New Lft Rev 1(215):3-15

Schulze-Cleven T, Reitz T, Maesse J, Angermuller J (2017) The new political economy of higher education: between distributional conflicts and discursive stratification. High Ed 73:795-812

Schwartz-Shea P, Yanow D (2012) Interpretive research design: concepts and processes. Routledge, London

Schwatz-Shea P (2006) Judging quality: evaluative criteria and epistemic communities. In: Yanow D, Schwartz-Shea P (eds) Interpretation and method: empirical research methods and the interpretive turn. Sharpe, New York, pp. 89-114

Sen A (1999) Development as freedom. Knopf Press, New York

Slembrouck S (2001) Explanation, interpretation and critique in the analysis of discourse. Crit Anthrop 21:33-57

Stubbs M (1997) Whorf's children: critical comments on critical discourse analysis. In: Ryan A, Wray A (eds) Evolving models of language. Multilingual Matters, Clevedon, pp. 100-116

Todd J (2016) The UK's relationship with Europe. Palgrave Macmillan, London

Tooley J (1999) The global education industry: lessons from private education in developing countries. International finance corporation and institute of economic affairs. http://documents.worldbank.org/curated/en/134581468178162812/Theglobal-education-industry-lessons-from-private-education-in-developingcountries. Accessed 5 July 2018

Turner JH (1985) In defence of positivism. Soc Thry 3:24-30

UNESCO (2002) EFA Global Monitoring Report 2002: is the world on track? UNESCO. https://unesdoc.unesco.org/ark:/48223/pf0000129777. Accessed 13 Sep 2017 
UNESCO (2005) EFA Global Monitoring Report 2005. Education for all: the quality imperative. UNESCO. https://unesdoc.unesco.org/ark:/48223/pf0000137333. Accessed 27 Nov 2017

UNESCO (2017) EFA Global Monitoring Report 2017/18. Accountability in education: meeting our commitments. UNESCO. https://unesdoc.unesco.org/ ark:/48223/pf0000259338. Accessed 9 Nov 2017

UNICEF (2004) Strategies for girls' education. UNICEF. https://www.unicef.org/ publications/index_21345.html. Accessed 15 Nov 2017

UNICEF (2009) All children, everywhere. UNICEF. https://www.unicef.org/ publications/index_50671.html. Accessed 14 March 2018

van Leeuwen TJ, Wodak R (1999) Legitimizing immigration control: a discoursehistorical analysis. Disc Stu 1(1):83-119

Vavrus F, Seghers M (2010) Critical discourse analysis in comparative education: a discursive study of 'partnership' in Tanzania's poverty reduction policies. Comp Ed Rev 54(1):77-103

Weimer DL, Vining AR (2011) Policy analysis, 5th edn. Longman, London

White H (1973) Metahistory: the historical imagination in nineteenth-century Europe. Johns Hopkins University Press, Baltimore

Whitty G (1997) Creating quasi-markets in education: a review of recent research on parental choice and school autonomy in three countries. Rev Res Ed 22:3-47

Whyman PB, Petrescu AI (2017) The economics of Brexit: a cost-benefit analysis of the UK's economic relationship with the EU. Palgrave Macmillan, London

Widdowson H (1995) Discourse analysis: a critical view. Lang Lit 4:157-172

Wodak R (2001) The discourse-historical approach. In: Wodak R, Meyer M (eds) Methods of critical discourse analysis. SAGE, London, pp. 63-94

Wodak R, Matouschek B (1993) We are dealing with people whose origins one can clearly tell just by looking: Critical Discourse Analysis and the Study of Neoracism in Contemporary Austria. Disc Soc 4(2):225-248

Wodak R, Weiss G (2005) Analyzing European union discourses: theories and applications. In: Wodak R, Chilton P (eds) A new agenda in critical discourse analysis: theory, methodology and interdisciplinarity. Benjamins, Amsterdam, pp. $121-135$

Woodhall M (2001) Human capital: educational aspects. In: Smelter NJ, Baltes PB (eds) International encyclopedia of the social and behavioral science. Elsevier, Oxford, pp. 6951-6955

World Bank (2003) Lifelong learning in the global knowledge economy: challenges for developing countries. World Bank. http://www.voced.edu.au/content/ ngv:29323. Accessed 30 Aug 2017

World Bank (2007) World Development Report 2007: development and the next generation. World Bank. https://openknowledge.worldbank.org/handle/ 10986/5989. Accessed 22 Feb 2018

World Bank (2011) Learning for all: investing in people's knowledge and skills to promote development. World Bank. http://siteresources.worldbank.org/EDUCATION/ Resources/ESSU/463292-1306181142935/WB_ES_ExectiveSummary_FINAL.pdf. Accessed 9 May 2018

Xiong T (2012) Discourse and marketization of higher education in China: the genre of advertisements for academic posts. Disc Soc 23(3):318-337

Yanow D (2000) Conducting interpretive policy analysis. Sage Publications, Thousand Oaks
Yanow D (2003) Constructing race and ethnicity in America: category-making in public policy and administration. Routledge, London

Yanow D (2006) Thinking interpretively: philosophical presuppositions and the human sciences. In:Yanow D, Schwartz-Shea $\mathrm{P}$ (eds) Interpretation and method: empirical research methods and the interpretive turn. Sharpe, New York, pp. 5-26

Zappettini F (2019) The official vision for 'global Britain': Brexit as rupture and continuity between free trade, liberal internationalism and 'values'. In:Koller K, Kopf S, Miglbauer M (eds) Discourses of Brexit. Routledge, New York, pp. $140-154$

Zhang Y, O’Halloran KL (2013) 'Toward a global knowledge enterprise': university websites as portals to the ongoing marketization of higher education. Crit Disc Stud 10(4):468-485

\section{Acknowledgements}

I am indebted to Dr. Oliver Daddow for his insightful comments on an earlier draft of this article.

\section{Competing interests}

The author declares no competing interests.

\section{Additional information}

Correspondence and requests for materials should be addressed to I.W

Reprints and permission information is available at http://www.nature.com/reprints

Publisher's note Springer Nature remains neutral with regard to jurisdictional claims in published maps and institutional affiliations.

cc (i) Open Access This article is licensed under a Creative Commons Attribution 4.0 International License, which permits use, sharing, adaptation, distribution and reproduction in any medium or format, as long as you give appropriate credit to the original author(s) and the source, provide a link to the Creative Commons license, and indicate if changes were made. The images or other third party material in this article are included in the article's Creative Commons license, unless indicated otherwise in a credit line to the material. If material is not included in the article's Creative Commons license and your intended use is not permitted by statutory regulation or exceeds the permitted use, you will need to obtain permission directly from the copyright holder. To view a copy of this license, visit http://creativecommons.org/ licenses/by/4.0\%

(c) The Author(s) 2020 